\title{
Effects of different curing conditions on the properties of geopolymeric mortar
}

\begin{abstract}
Background: As a result of industrialization, a lot of research is being done on alternative procedures for the production of normal Portland cement, which has an important role in reducing this emission from the construction sector in recent years, due to the increased $\mathrm{CO}_{2}$ emissions and environmental pollution caused by it. Geopolymer concrete studies, which are known to cause less $\mathrm{CO}_{2}$ emissions as a result of these researches in the construction sector, come to the fore. The aim of this study was to investigate the effect of different curing conditions on three different types of waste material (fly ash (FA), slag (GGBFS) and glass powder (GP) plus ) in geopolymer concrete. Alkaline activators based on sodium hydroxide $(\mathrm{NaOH})$ and sodium silicate $\left(\mathrm{Na}_{2} \mathrm{SiO}_{3}\right)$ were used as binders. The prepared samples were subjected to two different curing conditions which are the subject of our research. These curing conditions are respectively; in the first method, steam curing (SC) at $85^{\circ} \mathrm{C}$ for 12 hours, followed by standard cure at $20 \pm 3^{\circ} \mathrm{C}$ until the test date, and normal water cure (WC) based on curing at $20^{\circ} \mathrm{C}$ in the second method. In addition, the mixture groups were created by considering the different waste materials rate known as $0,1,2,3,4$ and 5 . Studying and investigating the low carbon dioxide emissions, compressive strengths, high flexural, practically low shrinkage, density, economic savings, reducing the waste material, are the main benefits of this paper. When the results of this study are examined that using FA, GP, and GGBFS positively affected the specimens with watercured, while GGBFS was negatively affected. And also under steam-cured conditions (SC) all specimens showed higher 2-days strength, while later compressive strengths were either higher or lower than those in water-cured conditions (WC), depending on the proportion of the waste material type.
\end{abstract}

Keywords: fly ash, geopolymer mortar, sodium silicate, sodium hydroxide, slag, compressive, flexural, strength

\section{Introduction}

Despite an increase in cement production by about $3 \%$ annually, the demand for Portland cement (PC) has now reached more than 1.6 billion tons per year worldwide as the product is still regarded as the essential material in industrial concrete. According to the global demand for Portland cement (PC), the forecasts show that will increase over the next 40 years. ${ }^{1}$ However, ordinary was calculated Portland cement (OPC) is a major enhancer of $\mathrm{CO}_{2}$ release into the atmosphere. In 2016, this amount is at $1.45 \pm 0.20 \mathrm{Gt} \mathrm{CO}_{2}$; in other words, roughly $8 \%$ of the entire anthropogenic $\mathrm{CO}_{2}$ emission. ${ }^{2}$ Apart from this, $\mathrm{SO}_{3}$ and $\mathrm{NOx}$ are a by product of emissions from the cement industry, leading to acid rain and the greenhouse effect. ${ }^{3,4}$ There are also other by-products, about $5 \%$ to $10 \%$, that go into the atmosphere along with these gases in the form of dust from the dryers, factories, furnaces, coolers and transportation facilities. In addition, the energy demands about 1700-1800 $\mathrm{MJ} /$ tons clinker consumes $1500 \mathrm{Kg}$ of raw materials. ${ }^{5,6}$ In this respect, waste disposal is the safe and effective removal of sewage and another major challenge facing industries. Sludge and large quantities of fly ash are produced during the combustion of coal. In 2010, the amount of the fly ash produced annually was about $780 \times 10^{6}$ tons. ${ }^{7,8}$ This ash is disposed in landfills in suitable locations, which is not exactly the best option due to high cost of operations as well as potential future consequences associated with landfills of this kind. ${ }^{9}$ More specifically, the main risk for ash landfilling is ground water contamination caused by elevated levels of toxic metals underground. To avoid this, certain procedures should be followed to dispose hazardous waste, such as controlled release into ground water and seepage water through safe chemical encapsulation and structural stability with respect to the current
Volume 5 Issue I - 2019

\author{
Hasbi Yaprak,' Abdoslam Alnkaa, ${ }^{2}$ Selçuk \\ Memiș,' Gökhan Kaplan' \\ 'Department of Civil Engineering, Engineering and Architecture \\ Faculty, Turkey \\ ${ }^{2}$ Department of Materials Science and Engineering, Institute of \\ Science, Turkey
}

Correspondence: Selçuk Memiș, Department of Civil Engineering, Engineering-Architecture Faculty, Kastamonu University, 37 I 50 Kastamonu, Tel +090 36628029 25, Turkey, Emailsmemis@kastamonu.edu.tr

Received: February 15, 2019 | Published: February 26, 2019 environmental settings. ${ }^{8,10}$ As result of these environmental problems, the scientific community has undertaken to seek new technologies, processes or materials with regard to the construction industry and as alternative materials, thereby reducing the amount of cement used in blends. In this respect, there are initiatives to utilize a new cement less binder material based on by-products as FA, slag or burned clay, ${ }^{11}$ and other alumino-silicate materials. These new materials are likely to replace $\mathrm{OPC}$ and be regarded as the new binder materials by alkali activation while generating less carbondioxide than OPC. Based on the estimates, alkali-activated concrete will produce $70 \%$ less $\mathrm{CO}_{2}$ than OPC and involve approximately $60 \%$ less energy consumption than that. ${ }^{8}$ Materials that are activated with alkali can be designed to have superior properties compared to OPC, better resistance to acid and sulfate, better heat resistance, ${ }^{12-14}$ less drying shrinkage and higher value of compressive strength. ${ }^{2}$ On top of these, reducing the $\mathrm{CO}_{2}$ emission by $26-45 \%$ by replacing OPC with no adverse economic effects is the main benefit of geopolymer concrete. ${ }^{15,16}$ When fly ash and glass powder are applied in the right proportions using a curing method, the mixture can decrease the cost without affecting the strength of the geopolymer mortar. ${ }^{17}$ In line with these developments, the mixture of slag and fly ash binders has also received a lot of attention in an attempt to create more advanced geopolymer material and many studies are being conducted in order to gain new perspectives as to their coexistence in the same binding system and to find an optimum design ratio between these components. ${ }^{18}$ In the present study, we investigate the impact of (slag and fly ash+glass powder) on the strength properties of water-cured and steam-cured (slag/fly ash+glass powder) blends activated with sodium hydroxide and sodium silicate. ${ }^{19,20}$ 


\section{Materials and methods}

\section{Ground granulated blast-furnace slag (GGBFS)}

In this study, the GGBFS was provided from the Ereğli Iron-Steel Factory (Oyak) in Turkey with a specific gravity (S.G) of $2.81 \mathrm{~g} / \mathrm{cm}^{3}$ and a fineness of $4250 \mathrm{~cm}^{2} / \mathrm{g}$. The chemical composition is shown in Table 1.

Table I The chemical composition of GGBFS, GP and FA (\%)

\begin{tabular}{lllllllll}
\hline Oxide & $\mathrm{SiO}_{2}$ & $\mathrm{Al}_{2} \mathbf{O}_{3}$ & $\mathrm{Fe}_{2} \mathrm{O}_{3}$ & $\mathrm{CaO}$ & $\mathbf{M g O}$ & $\mathbf{S O}_{3}$ & $\mathbf{K}_{2} \mathbf{O}$ & $\mathbf{N a}_{2} \mathbf{O}$ \\
\hline GGBFS & 36.7 & 5.2 & 0.98 & $32.6 \mathrm{I}$ & 10.12 & 0.99 & 0.76 & 0.42 \\
FA & $61.8 \mathrm{I}$ & 26 & $7.0 \mathrm{I}$ & 1.77 & 2.56 & $0.3 \mathrm{I}$ & 0.99 & 2.43 \\
$\mathrm{GP}$ & 72.66 & 1.57 & 0.39 & $11.4 \mathrm{I}$ & 1.24 & 0.07 & 0.54 & 12.89 \\
\hline
\end{tabular}

\section{Waste glass (GP)}

Table 1 shows the chemical composition of the glass powder. The value of $\mathrm{CaO}, \mathrm{Na}_{2} \mathrm{O}$ contents are about $11 \%$ and $13 \%$, respectively, while the value of $\mathrm{SiO}_{2}+\mathrm{Al}_{2} \mathrm{O}_{3}+\mathrm{Fe}_{2} \mathrm{O}_{3}$ exceeds $70 \%$. A ball mill is used to waste glass grounded, which to produce finer ash, will be grounded by a small mill. The mean diameter of the particle size is $13 \mu \mathrm{m}$ at a density of $2.56 \mathrm{~g} / \mathrm{cm}^{3}$ and a fineness of $5320 \mathrm{~cm}^{2} / \mathrm{g}$.

\section{Standard aggregate}

Table 2 shows the sieve analysis produced by Limak Cement. All the aggregate was used standard aggregate in accordance with the TS EN $196-1$ at the maximum size of $2 \mathrm{~mm}$.

Table 2 Sieve analysis ${ }^{19}$

\begin{tabular}{ll}
\hline Size of sieve $(\mathbf{m m})$ & Remaining cumulative (\%) \\
\hline 2 & 0 \\
1.6 & $7 \pm 5$ \\
1 & $33 \pm 5$ \\
0.5 & $67 \pm 5$ \\
0.16 & $87 \pm 5$ \\
0.08 & $99 \pm 1$ \\
\hline
\end{tabular}

\section{Alkali activator}

As binder materials used sodium silicate and sodium hydroxide that is an alkali activator, where the modulus of sodium silicate $\mathrm{Na}_{2} \mathrm{SiO}_{3} /$ $\mathrm{NaOH}$ is equal to 1 and the concentration of sodium hydroxide is $16 \mathrm{M}$ (molarite).

\section{Methods}

\section{Preparation of specimen mixtures}

The aim is to investigate blended slag, glass powder and fly ash alkali-activated mortars with a water ratio (S/B) of 0.33 to the binder. In conformity with TS-EN 196-1, the standard aggregate, GGBFS, GP, FA, water, $\mathrm{Na}_{2} \mathrm{SiO}_{3}$, and $\mathrm{NaOH}$ are used in the production of these geopolymer mortars. In addition, the amount of the binder GGBFS+FA+GP is kept constant at an $810.5 \mathrm{~g} / 1000 \mathrm{~g}$ standard aggregate. Table 3 reveals the ingredients of the mortar mixtures. In the first type, which is the water-cured (WC) series, the specimens were immersed in the water at $20^{\circ} \mathrm{C}$ for 28 days; whereas, in the second type, that is the steam cured (SC) series, the specimens were $\mathrm{SC}$ at $85^{\circ} \mathrm{C}$ for $12 \mathrm{~h}$.

\section{Fly ash (FA)}

The study was conducted at the Çatalağzı Thermal Power Station (Çatalağzi, Zonguldak-Turkey). Table 1 shows the chemical properties of the FA. The value of $\mathrm{CaO}$ content is less than $10 \%$, while the value of $\mathrm{SiO}_{2}+\mathrm{Al}_{2} \mathrm{O}_{3}+\mathrm{Fe}_{2} \mathrm{O}_{3}$ exceeds $70 \%$. Then, the current $\mathrm{FA}$ is classified as class F fly ash. The specific gravity of the FA was $2.39 \mathrm{~g} /$ $\mathrm{cm}^{3}$ and the fineness was $6000 \mathrm{~cm}^{2} / \mathrm{g}$.

\section{Casting of the specimens}

Table 3 shows the mix proportions as a predefined order, followed by mixing in a Hobart mixer (Figure 1). For the purpose of gaining added homogeneity to allow smooth $\mathrm{SiO}_{2}$ and $\mathrm{NaO}_{2}$ release in the mortar, the water and sodium hydroxide were combined in a glass jar up to the point of their complete dissolution. The mixing process is shown in Figure 2.

Table 3 Mortar mixture ingredients

\begin{tabular}{llll}
\hline Mix & GGBFS & FA & GP \\
No & $\%$ & $\%$ & $\%$ \\
\hline 0 & 100 & 0 & 0 \\
1 & 90 & 5 & 5 \\
2 & 90 & 0 & 10 \\
3 & 90 & 10 & 0 \\
4 & 80 & 10 & 10 \\
5 & 70 & 15 & 15 \\
\hline
\end{tabular}

1: $\mathrm{FA}+\mathrm{GGBS}+\mathrm{GP} \quad 2: \mathrm{Na}_{2} \mathrm{SiO}_{3}+\mathrm{NaOH} \quad 3:$ Standard aggregate 4:Admixture(CHRYSO)+ water 5: Geopolymer mortar

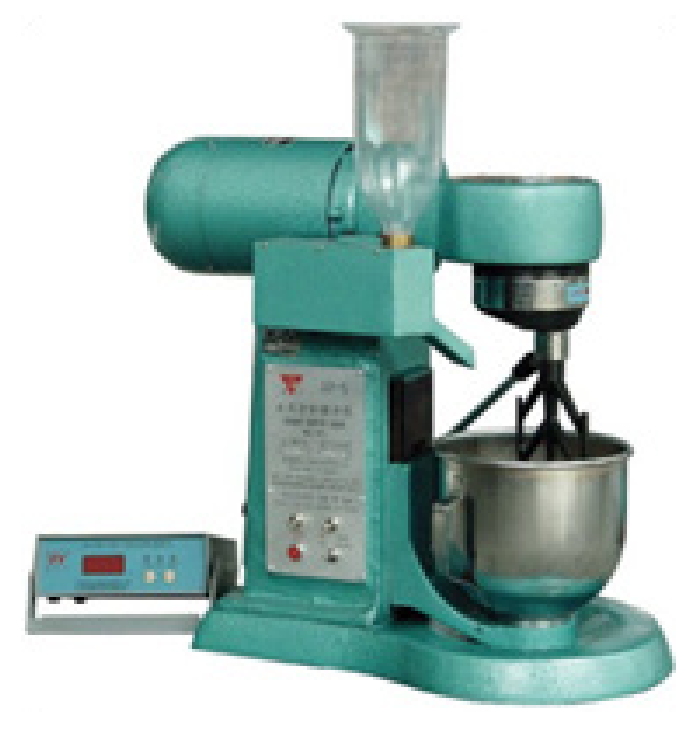

Figure I The Hobart mixer. 


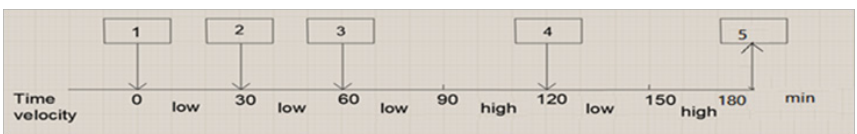

Figure 2 Mortar mixing

\section{Results and discussion}

\section{Compressive and flexural strength}

The specimen sizes were $4 \times 4 \times 16 \mathrm{~cm}$ for compressive strength testing with a $2.4 \mathrm{KN} / \mathrm{s}$ loading rate. Both the compressive and flexural strength of the specimens tested according to TS-EN1961. Furthermore, compressive strength and flexural strength were measured at hardened state at 2, 7,28 and 90 days. The testing machine and apparatus utilized in the compressive and flexural strength testing and some of the specimens appear in Figure $3 \&$ Tables 4-7.The geopolymer mortar with water to binder ratio $\mathrm{W} / \mathrm{B}$ is 0.33 where the effect of curing conditions on compressive strength is shown in Figure 4A. The steam curing results after 7 days are much higher compared to the strength than in the case of water curing at 28 days. Respectively, the values of the compressive strengths corresponding to steam curing for SC0-SC1-SC2 were 72.1 MPa, 75.8 MPa, and 69.7 MPa, as shown in Figure 4. Furthermore, these values were 5 times, 1.4 times and 3.1 times as much as those after water curing for $\mathrm{WC} 0$, WC1, and $\mathrm{WC} 2$, respectively. Moreover, it can be noted from Figure 4A that the compressive strength of both of these mortar types within 2 days increased to the maximum value before gradually decreasing. Figure 4(A \&B) shows the compressive strength of the water cured specimens for (WC1, WC3, WC4, and WC5) after 28 days, where the values are either equal or have insignificant differences compared to steam curing. Based on Figure 4A, the compressive strength values of all mortars decrease but remain close to each other in between 64.6 and $63.2 \mathrm{MPa}$, when (the slag and fly ash+glass powder ratio) ranges between 80/20 to 70/30. From Figure 4B, it can be observed that the GGBFS/FA ratio is a very important factor regarding the compressive strength values of mortars under water-cured conditions. At 90 days of testing, the compressive strength value was $78.2 \mathrm{MPa}$ when the proportion of the ingredient mortar was $90 \%, 10 \%$, and $0 \%$ for GGBFS, FA, and GP, respectively. Furthermore, as can be seen from the Figure 4, the compressive strength values of the S1, S3, S4 and S5, and those of all these geopolymer mortars with $\mathrm{WC}$ and SC remained close to each other and between $65 \mathrm{MPa}$ and $78.2 \mathrm{MPa}$. Generally, the test results indicate that there is an equal crack in all the four exposed faces with slight or no damage to the top and bottom contact faces with the platens. These cracks appeared in a vertical zigzag pattern with a failure pattern as in Figure 3. Figure 5(A \&B) shows that the flexural strength of the steam-cured geopolymer (SC1, SC2, SC3) after 7 days increased to a maximum value before a gradual decline afterward. The flexural strengths values after 7 days were $3.9 \mathrm{KN}$, $3.6 \mathrm{KN}$ and $3.2 \mathrm{KN}$, respectively, while after 28 days were $2.7 \mathrm{KN}$, $2.5 \mathrm{KN}$ and $2.2 \mathrm{KN}$. The flexural strength results under water-cured conditions for 28 days (CS4) recorded the maximum value $2 \mathrm{KN}$. Overall, these evaluations reveal that the steam curing conditions resulted in a higher early age ( 2 days) strength, while water curing developed longer-term strength in the specimens. According to Figure 6 , the 28-day specimens presented greater compressive strength in the case of SC geopolymer mortar compared with the WC geopolymer mortar. In addition, it can be observed that the strength values of the 7-day SC geopolymer specimens are greater than that of 28-day WC specimens. It has to be noted that an increase in the FA content in the mixture has a beneficial influence on the compressive strength up to $70 / 30$ GGBFS and FA+GP ratio under WC conditions. In the meantime, reduced amounts of FA appear to have a detrimental or counter-productive effect on the mortar. When comparing maximum compressive strength values achieved under each curing condition, the WC specimens showed higher values than the SC ones at the end of their respective curing period, as can be seen in Figure 7 .

Table 4 The compressive strength results of steam curing (SC)

\begin{tabular}{lllllll}
\hline & \multicolumn{6}{c}{ Compressive results for steam curing $($ SC) MPa } \\
\cline { 2 - 7 } Days & SC0 & SCI & SC2 & SC3 & SC4 & SC5 \\
\hline 2 & 65.5 & 71.9 & 52.8 & 65.3 & 64.4 & 60.8 \\
7 & 68.4 & 75.7 & 69.6 & 65.1 & 66.3 & 61.7 \\
28 & 72.1 & 75.8 & 69.7 & 67 & 64.6 & 63.2 \\
90 & 76.3 & 77.1 & 74.2 & 65 & 75.6 & 72.9 \\
\hline
\end{tabular}

Table 5 The compressive strength results of water curing (WC)

\begin{tabular}{lllllll}
\hline & \multicolumn{7}{c}{ Compressive results for water curing } & (WC) \\
\cline { 2 - 7 } Days & WC0 & WCI & WC2 & WC3 & WC4 & WC5 \\
\hline 2 & 4.1 & 10.9 & 5.2 & 13.4 & 17.8 & 13.9 \\
7 & 7.5 & 30.2 & 11.4 & 31.3 & 28.8 & 30.6 \\
28 & 14.4 & 54.1 & 22.2 & 58.3 & 54.7 & 56 \\
90 & 42.7 & 76.8 & 46.2 & 78.2 & 74.4 & 67.9
\end{tabular}

Table 6 The flexural strength results of steam curing (SC)

\begin{tabular}{lllllll}
\hline & \multicolumn{6}{l}{ Flexural results for water curing (WS) KN } \\
\cline { 2 - 7 } Days & SC0 & SCI & SC2 & SC3 & SC4 & SC5 \\
\hline 2 & 2.3 & 3.1 & 3 & 3 & 2.5 & 2.4 \\
7 & 2.5 & 3.9 & 3.6 & 3.2 & 3.2 & 2.2 \\
28 & 2.6 & 2.7 & 2.5 & 2.2 & 2.2 & 1.8 \\
90 & 3.7 & 3.5 & 3.3 & 3.3 & 3.5 & 3.2 \\
\hline
\end{tabular}

Table 7 The flexural strength results of water curing (WC)

\begin{tabular}{lllllll}
\hline & \multicolumn{6}{l}{ Flexural results for water curing (WC) KN } \\
\cline { 2 - 7 } Days & WC0 & WCI & WC2 & WC3 & WC4 & WC5 \\
\hline 2 & 0.3 & 0.3 & 0.3 & 0.3 & 0.3 & 0.3 \\
7 & 0.4 & 0.4 & 0.4 & 0.4 & 0.4 & 0.4 \\
28 & 0.8 & 0.8 & 0.8 & 0.8 & 0.8 & 0.8 \\
90 & 2.6 & 2.6 & 2.6 & 2.6 & 2.6 & 2.6
\end{tabular}

\section{Water absorption}

The specimens were dried in an oven for 24 hours in $105 \square$ and later, placed in a desiccator to cool. In the water-absorption test, the specimens are weighed (W2) immediately upon cooling. Generally speaking, $23^{\circ} \mathrm{C}$ for 24 hours until equilibrium was the condition emerged in water at agreed upon conditions. Specimens were removed, patted dry with a lint-free cloth and weighed (W1).

$$
\% \text { Absorbent of water }=\frac{W 1-W 2}{W 2} * 100
$$

Where:

$\mathrm{W} 1=$ weight of specimen after immersion in water for 24 hours

$\mathrm{W} 2=$ Weight of specimen after oven drying at $100^{\circ} \mathrm{C}$ for 24 


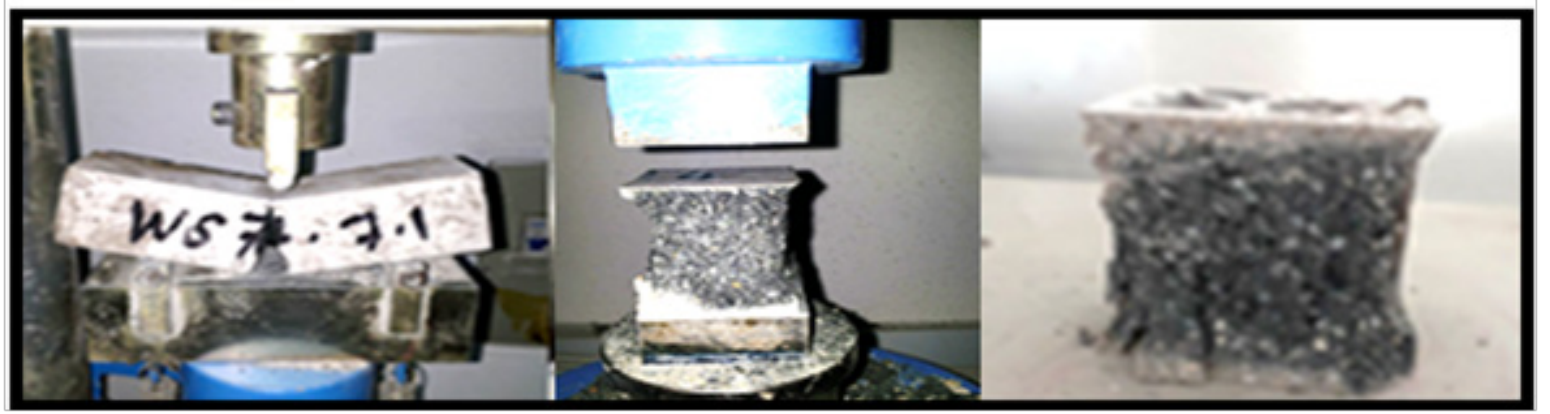

(a) Flexural strength

(b) Compressive strength

Figure 3 Failure pattern
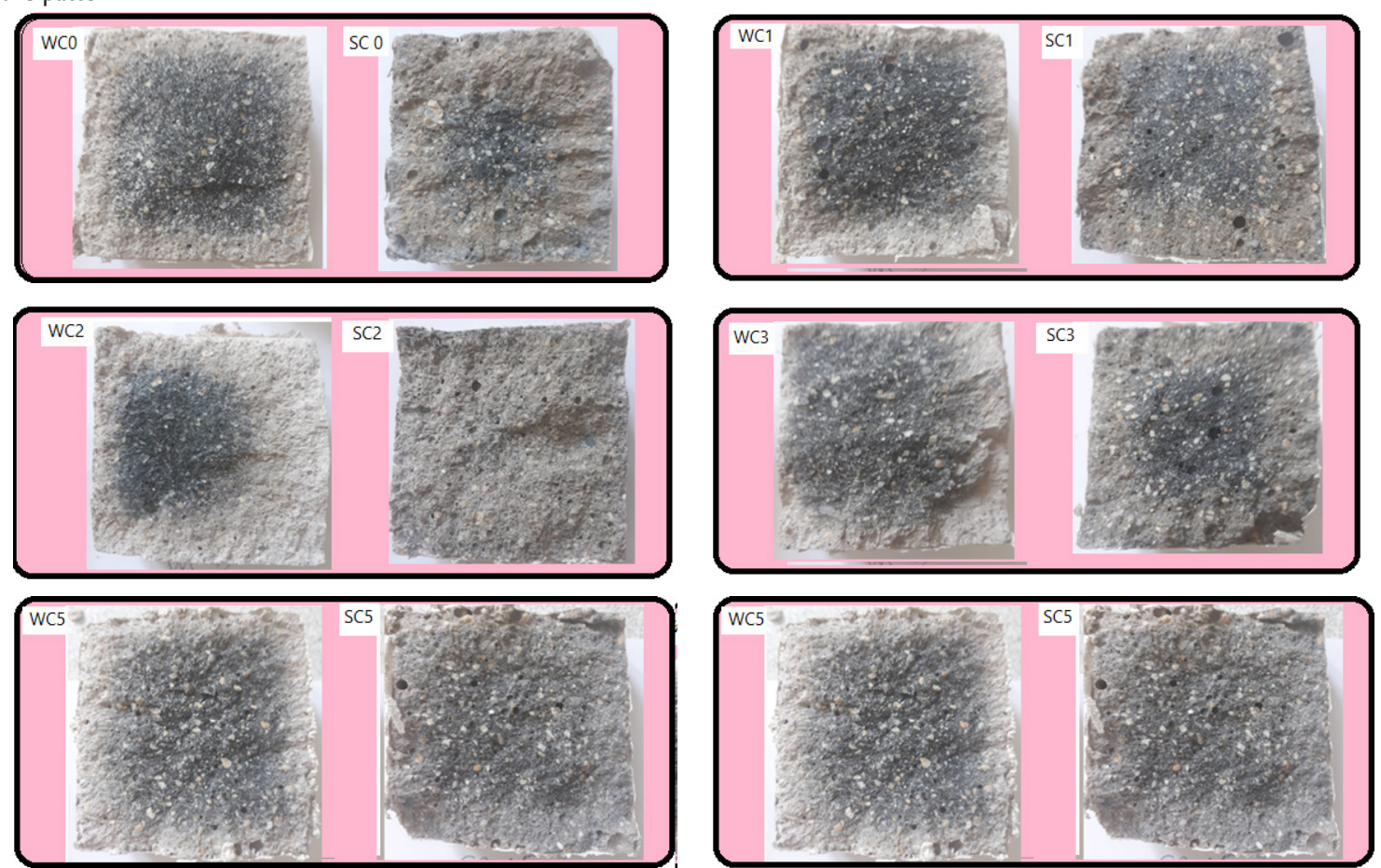

Figure 4 (A) Mortar sections

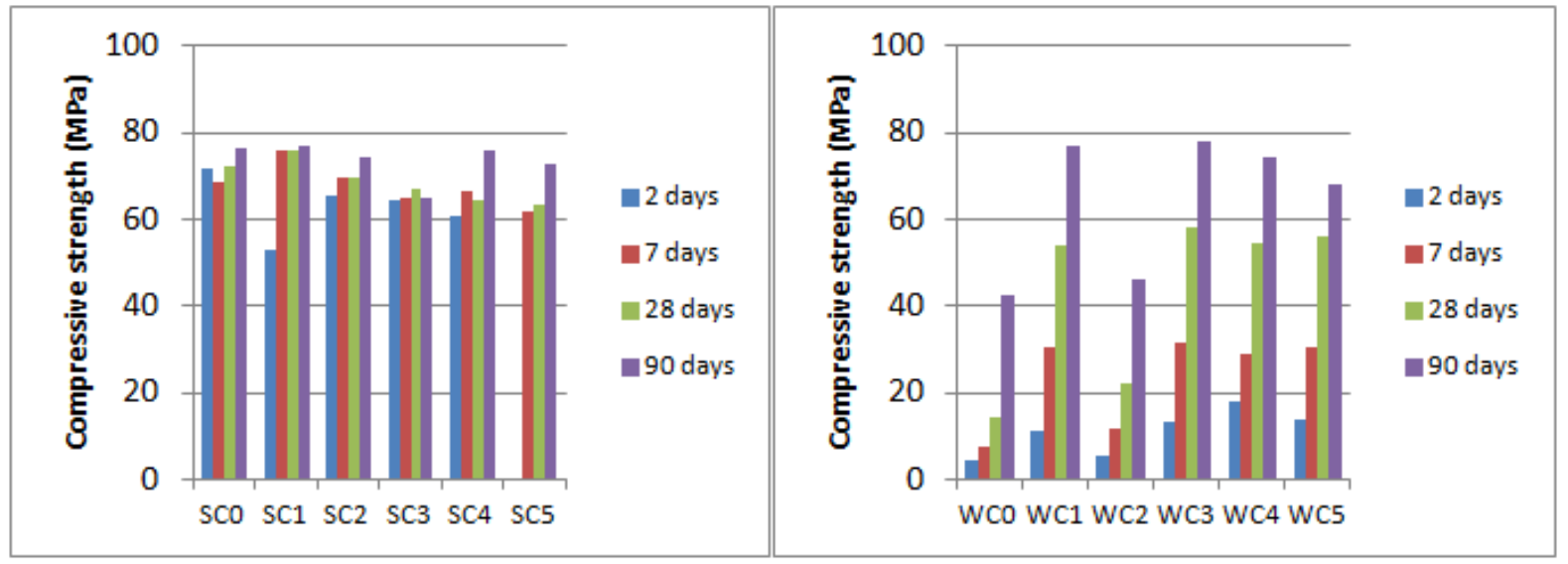

(a)

(b)

Figure 4 (B) The evolution of compressive strength according to mortar mixture ingredients ratio for (a) steam curing (SC) and (b) water curing (WC).

Citation: Yaprak H,Alnkaa A, Memiș S, et al. Effects of different curing conditions on the properties of geopolymeric mortar. MOJ Civil Eng. 2019;5(I):45-50. DOI: I0.15406/mojce.2019.05.00I 48 


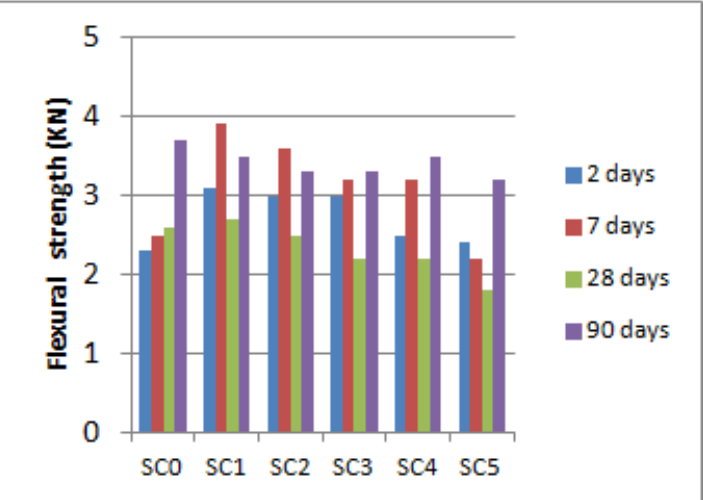

(a)

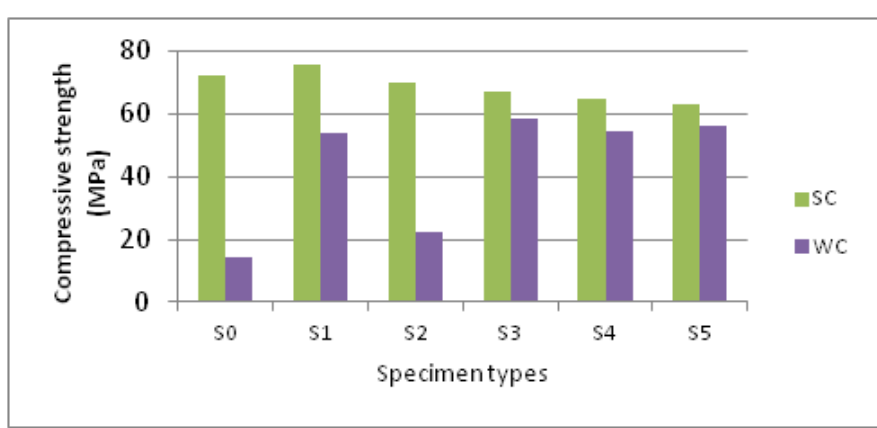

Figure 6 The relationship between specimen types and compressive strength for SC (steam-cured) and WC (water-cured) specimens at 28 days.

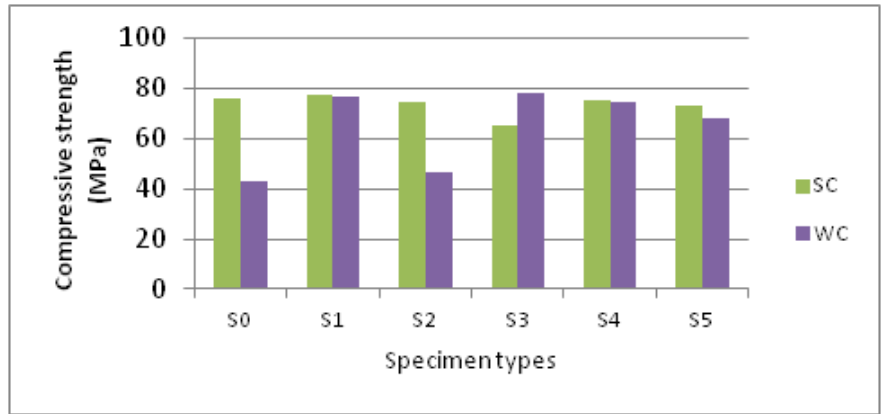

Figure $\mathbf{7 ( A )}$ The relationship between specimen types and compressive strength for SC (steam-cured) and WC (water-cured) specimens at 90 days.

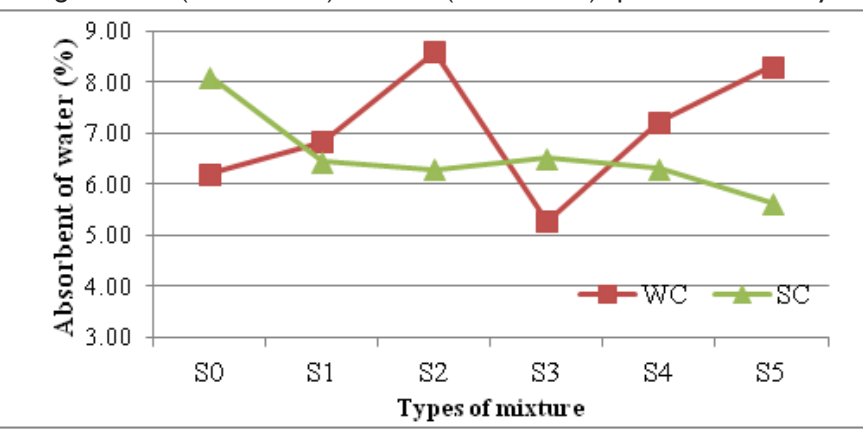

Figure 7(B) Water absorption for the steam-cured (SC) and water-cured (WC) specimens.

Table $8 \&$ Figure $7(A \& B)$ show the results of the water absorption test at 28 days, based on which water absorption is $8.1 \%$ for (SC0) followed by a significant increase to $9.29 \%$ for $\mathrm{SC} 2$, whereas this

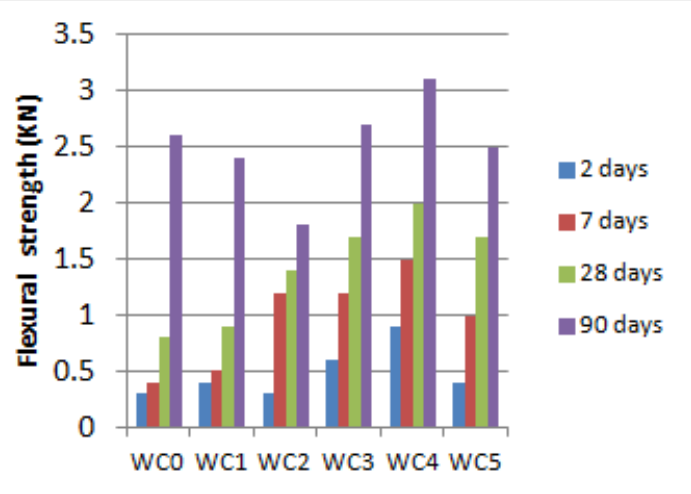

(b)

value drops to $5.45 \%$ for SC5. The results show that porosity and water absorption are significantly influenced by the fineness and shape of the slag, fly ash and glass powder precursors. The low value of water absorption in the case of the geopolymer mortar can be attributed to the fineness of the fly ash precursor $\left(6000 \mathrm{~cm}^{2} / \mathrm{g}\right)$ compared to that of the slag precursor $\left(4250 \mathrm{~cm}^{2} / \mathrm{g}\right)$ and glass powder precursor $\left(5320 \mathrm{~cm}^{2} / \mathrm{g}\right)$ as suggested by Neville. These results imply that increased fineness affects the distribution of the material within the specimen and fills the cracks between the aggregates that case of less water absorption. Raising FA and GP leads to a reduction of water absorption as shown in Figure 7(A \&B). In fact, it's the steamcured condition, while was observed in water cured condition when increasing FA and GP, lead to increase absorption water coefficient. In the Figure 8(A \&B) shows the effects of absorption on compressive strength, where water absorption under SC and WC has no clear relationship with compressive strength. For this reason, the strength of concrete cannot be assessed based on the degree of water absorption.

Table 8 Water absorption test

\begin{tabular}{lll}
\hline Mixture & $\begin{array}{l}\text { Absorption. } \\
\text { for SC }\end{array}$ & $\begin{array}{l}\text { Absorption } \\
\text { for WC }\end{array}$ \\
\hline 0 & 8.102 & 6.212 \\
1 & 5.451 & 6.838 \\
2 & 9.296 & 7.591 \\
3 & 6.15 & 5.27 \\
4 & 6.304 & 7.223 \\
5 & 5.639 & 8.318 \\
\hline
\end{tabular}

\section{Conclusion}

This study aimed to describe the importance and the special requirements of waste material to be used in geopolymer mortar. The results obtained address the issue with the purpose to a) obtain a mortar that satisfies the optimal grout property requirements, and b) the degree of effectiveness related to physical and mechanical characteristics and depending on the curing conditions, steam or water. Accordingly, we analyzed these values with alkali-activated, GGBFS, GP and FA blend mortars mixed with hydroxide sodium and silicate sodium. The experimental results offered the outcomes as follow:

I. The compressive strength of steam curing (SC) at $85^{\circ} \mathrm{C}$ for $12 \mathrm{~h}$ and 2 days recorded higher strength values, which is more than 
water-immersed curing conditions at an early age. Meanwhile, with 28 days, water-immersed curing showed comparable or higher mechanical strength as well as a maximum compressive strength at (WC3) $58.3 \mathrm{MPa}$.

II. Adding fly ash and glass powder to the slag led to improving the strength at early ages under water curing (WC) conditions for geopolymeric mortars.

III. The high-strength geopolymeric mortar with a compressive strength in the order of $75.82 \mathrm{MPa}$ at 28 days can be obtained by activating GGBFS, GP and FA ( $90 \%, 5 \%$, and $5 \%)$ blends with sodium met silicate under steam water curing (WC) condition.

IV. The high-strength geopolymeric mortar with the compressive strength in the order of $58.3 \mathrm{MPa}$ at 28 days can be obtained by activating GGBFS, GP and FA $(85 \%, 0 \%, 10 \%)$ blend with sodium silicate under water curing (WC) conditions.

V. For geopolymer mortars, that produced slag, fly ash and glass powder, steam curing (SC) is more appropriate than water curing (WC).

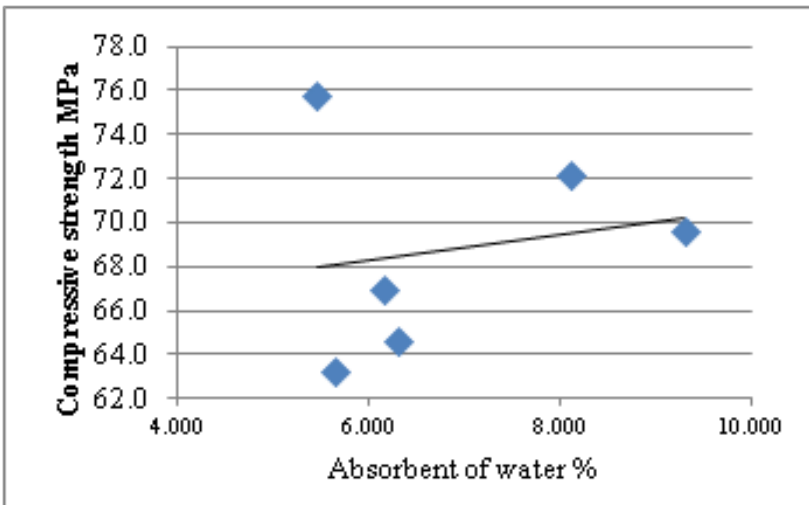

(A)

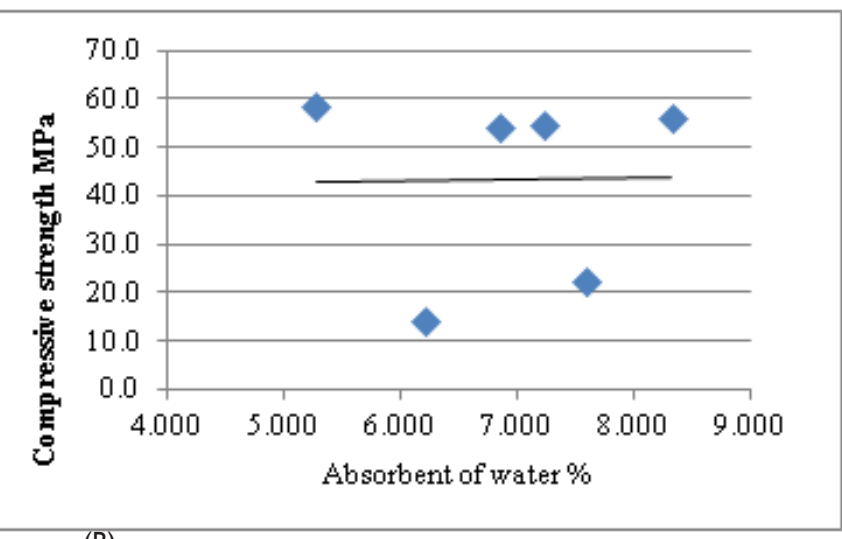

(B)

Figure 8 The relationship between water absorption and compressive strength for (a) steam-cured (SC) and (b) water-cured (WC) specimens at 28 days.

\section{Acknowledgments}

Hasbi Yaprak conceived and designed the experiments; Abdoslam Alnkaa and Gökhan Kaplan performed the experiments; Hasbi Yaprak and Selçuk Memiş analyzed the data; Selçuk Memiş and Abdoslam Alnkaa wrote the paper

\section{Conflicts of interest}

The authors declare there is no conflicts of interest.

\section{References}

1. Rashad AM. A comprehensive overview about the influence of different admixtures and additives on the properties of alkali-activated fly ash. Materials \& Design. 2014;53(1):1005-1025.

2. Luukkonen T. One-part alkali-activated materials: A review. Cement and Concrete Research. 2017;103():21-34.

3. Park SS, Kang HY. Characterization of fly ash-pastes synthesized at different activator conditions. Korean Journal of Chemical Engineering. 2008;25(1):78-83.

4. Rashad AM, Zeedan SR. The effect of activator concentration on the residual strength of alkali-activated fly ash pastes subjected to thermal load. Construction and Building Materials. 2011;25(7):3098-3107.

5. Taylor HF. Cement chemistry. 1997.

6. Rashad A. Hydration and properties of sodium sulphate activated slag. Cement and concrete composites. 2013;37(1):20-29.

7. Hardjito D. On the development of fly ash-based geopolymer concrete Materials Journal. 2004;101(6):467-472.

8. Khale D, Chaudhary R. Mechanism of geopolymerization and factors influencing its development: a review. Journal of materials science. 2007;42(3):729-746.

9. Ghosh K, Ghosh P. Effect of Variation of Slag Content on Chemical, Engineering and Micro structural Properties of Thermally Cured Fly Ash-Slag Based Geopolymer Composites. Rasayan J Chem.
2018;11(1):426-439.

10. Dutta D, Ghosh S. Parametric study of geopolymer paste with the different combination of activators. International Journal of Engineering Innovation \& Research. 2014;3(6):786-793.

11. Rashad AM. Alkali-activated metakaolin: A short guide for civil Engineer-An overview. Construction and Building Materials. 2013;41(1):751-765.

12. Kong DL, Sanjayan JG. Effect of elevated temperatures on geopolymer paste, mortar and concrete. Cement and concrete research. 2010;40(2):334-339.

13. Sarker PK, Mcbeath S. Fire endurance of steel reinforced fly ash geopolymer concrete elements. Construction and Building Materials. 2015;90(10:91-98.

14. Sarker PK, Kelly S, Yao Z. Effect of fire exposure on cracking, spalling and residual strength of fly ash geopolymer concrete. Materials \& Design. 2014;63(1):584-592.

15. Mc Lellan BC. Costs and carbon emissions for geopolymer pastes in comparison to ordinary Portland cement. Journal of cleaner production. 2011;19(9-10):1080-1090.

16. Habert G, De Lacaillerie JDE, Roussel N. An environmental evaluation of geopolymer based concrete production: reviewing current research trends. Journal of cleaner production. 2011;19(11):1229-1238.

17. Luga E. Svojstva čvrstoće mješavina zgure/letećeg pepela aktiviranih pomoću natrijevog metasilikata. Građevinar. 2017;69(3):199-205.

18. Provis JL. X-ray microtomography shows pore structure and tortuosity in alkali-activated binders. Cement and Concrete Research. 2012;42(6):855-864.

19. ENT. Methods of Tests for Masonry-Part 11: Determination of pressure and flexural strength of hardened mortar. Turkish Standardization Institute. 2000.

20. Krishanu Roy, Ali Akhtar, Sagar D, et al. Development and characterization of novel bio char-mortar composite utilizing waste derived pyrolysis bio char. International Journal of Scientific \& Engineering Research. 2017;8(12):1-1. 